\title{
The Risks of Organic Rice Farming: A Case Study in The Kebonagung Village Imogiri District and Wijirejo Village Pandak District Bantul Regency Special Region of Yogyakarta
}

\author{
Sriyadi \\ Departement of Agribusiness \\ Universitas Muhammadiyah Yogyakarta \\ Yogyakarta, Indonesia \\ sriyadi_s@yahoo.co.id
}

\begin{abstract}
This research aims to identify the level of organic rice farmers' decisions and the risks of organic rice farming. The research was conducted in the Kebonagung village of Imogiri district and Wijirejo villages of Pandak district Bantul Regency of special region of Yogyakarta with the survey and interview with the organic rice farmers. The first purpose was analyzed by the descriptive analysis to describe the decision of farmers. Meanwhile, the risks were tested by the coefficient variation. The results show that the decision of farmers toward the organic rice farming is good and organic rice farming has a lower risk than conventional and mixed systems.
\end{abstract}

Keywords: organic farming, rice, the risk

\section{INTRODUCTION}

Nowadays, people have started to realize the danger of the use of chemical fertilizers by farmers making the planted crops unhealthy for consumption. There is a tendency that people will change their way of selecting agricultural products by directly purchasing fresh products from farmers for healthier consumption. Direct purchase to farmers will enable them to buy fresher and healthier products to consume. . The assumption of returning to nature is one of the most appropriate choices to illustrate their desire.

An organic product including the organic rice is a food produced by organic farming [1]. An organic food is believed to be more secure [2] because it is a natural food that is produced without the chemicals and artificial fertilizers [3]. Organic food products are produced from the organic farming which is a production system that maintains the health of the soils, ecosystems and humans.

There have been many reports about the excessive use of pesticides which raises many damages for soil lately. Hence, the healthy food of high nutritional value that is produced by organic farmers is the only answer of today's consumer desires.

An organic agriculture is one of the choices that can be conducted by Indonesian farmers to get the food for the household level while it also recovers the soil quality, improve biodiversity, and provide a quality food for underprivileged society around. The benefits of organic agriculture have been proven by the system of organic farming that is integrated, economically and environmentally friendly, and improve the public health.
In 2009, three percent of 58,000 hectares of rice fields in Yogyakarta implemented the organic system, but only five percent of them were certified as organic. Each farmer has the different level of awareness and understanding on the organic farming, and thus leading to only a few numbers of farmers to implement the organic systems in their farming. The farmers worried about the failure risks if they use the organic fertilizer. They assumed that the implementation of the organic systems can reduce their farming production and some of them even do not understand clearly about the organic farming. Based on the problems above, it is necessary and interesting to investigate and examine the farmers' decision in implementing the organic farming on rice farming and the risks of organic farming on the rice farming. The purpose of this research is to know the decision of farmers in applying organic farming on the rice farming and to find out the cost, revenue, and the risks of organic farming on the rice farming.

\section{RESEARCH METHODOLOGY}

\section{A. Research Participants and Sampling}

This is a descriptive research [4] [5] [6] [7] aiming to analyze of the risks of organic rice farming through a survey research method on the organic rice farmers in the Kebonagung village of Imogiri district and Wijirejo village of Pandak district Bantul Regency Special Region of Yogyakarta. From each village, the researchers took 50 respondents totaling to 100 respondents. To collect the data, the researcher used the observation and interview guided by the questionnaire.

\section{B. Data Analysis}

To describe the decision of farmer in implementing the organic farming, this study used the descriptive analysis. The analysis of the cost and revenue can be derived from the following formula:

1. The cost

Total of cost (TC) is the total implicit cost plus the explicit cost that was stated in the following formula : 


$$
\begin{aligned}
& \text { TC }=\text { TIC }+ \text { TEC } \\
& \text { Explanation: } \\
& \text { TC }=\text { Total of cost } \\
& \text { TIC = Total of implicit cost } \\
& \text { TEC = Total of explicit cost }
\end{aligned}
$$

2. Income

From the calculated income of rice farmers, it is possible to apply the following formula:

$$
\begin{aligned}
& \mathrm{NR}=\mathrm{TR}-\mathrm{TEC} \\
& \text { Explanation: } \\
& \mathrm{NR}=\text { Income } \\
& \mathrm{TR}=\text { Acceptance } \\
& \mathrm{TEC}=\text { The explicit cost }
\end{aligned}
$$

3. To measure the risk, this study used the variation coefficient. The formula of the variation coefficient is the standard deviation divided by the average.

$$
\text { Variation Coefficient }=\frac{\text { Standard Deviation }}{\text { Average }}
$$

Standard deviation is the rank of a variant (variance)

$$
\sigma=\sqrt{\frac{\sum_{\mathrm{i}}^{\mathrm{n}}=1(\mathrm{xi}-\overline{\mathrm{x}}) 2}{\mathrm{n}}}
$$

Explanation:

$\sigma=$ Standard deviation

$\mathrm{Xi}=$ The value of income for- $\mathrm{i}$

$\bar{x}=$ The average value of the revenue, cost and acceptance

$\mathrm{N}=$ The number of samples

The amount of the risk that would be faced by farmers can be seen from the variation coefficient of farming. If the variation coefficient of farming is bigger, the risks faced by farmers are also bigger.

\section{RESULTS\&DISCUSSION}

\section{A. The Farmers' Decision}

\section{The Process of Making Decision}

Introduction. The introduction step begins when a person is aware of an innovation and obtains some understanding on how that innovation works. An introduction toward an organic fertilizer actually began since 1970 and was introduced by the elderly farmers who at that time still used a regular organic (compost). In 1985, it was begun with a government program of the introduction

\begin{tabular}{|c|c|c|c|}
\hline Year & Source & $\begin{array}{c}\text { Total number } \\
\text { (person) }\end{array}$ & $\%$ \\
\hline $1972-1983$ & The oldster & 4 & 4 \\
\hline $1985-2004$ & $\begin{array}{l}\text { Institution, Oldster, } \\
\text { Society } \\
\text { Institution, Society, }\end{array}$ & 35 & 35 \\
\hline & $\begin{array}{l}\text { Farmer group } \\
\text { Farmer group, Society, }\end{array}$ & 42 & 42 \\
\hline $2009-2018$ & Store & 19 & 19 \\
\hline
\end{tabular}
of organic fertilizer. This leads to the prominent fact that in the last 15 years, people are beginning to be aware of homemade organic fertilizer as demonstrated by farmer groups.

The organic fertilizers which were introduced in the 1970's was passed on from elderly farmers. The organic fertilizers of the past are no longer the same with todays' organic fertilizers. In the past, farmers only knew the organic fertilizers made of fermented manure. The farmer only utilized manure of the cattle that they fermented until it became a soil and can be used in the farmer's land.

In 1985, the Government tried to introduce organic fertilizer to farmers. By then, farmers have already started to try using organic fertilizer for their farming activities. Farmers consider that the use of organic fertilizer will give benefits on the soil fertility. Nevertheless, organic fertilizers require a lot of labor in the processing, making it is less desirable.

The difficulty to obtain a chemical fertilizer and the unaffordable price of that fertilizers makes the farmers try to use organic fertilizer. The program introduced by the Government and the rise of farmer groups in the making of organic fertilizer made farmers aware about organic fertilizers.

During the last 15 years, farmers have started to realize that excessive use of chemical fertilizers will damage the soil quality. Farmers' awareness is even more enhanced by the activities carried out by farmer groups and related institution about the organic fertilizers. Moreover, there have been cooperation between the Government and the store to provide farmers with free organic fertilizer for every purchase of the chemical fertilizer.

Persuasion. Farmers' attitude of accepting the current situation or lack of interest towards new innovation requires them to be psychologically involved with the innovation through the persuasion step. At this step, the public perception of the innovation was formed. Most of the farmers want to use organic fertilizers (74\%). It is showed that psychologically, the organic farming could be accepted by farmers.

The attitude of unacceptable to use the organic fertilizer is about 26 percent of the entire farmers as samples examined and with the varied reason. Complication in the processing, using land rent, and doubt about organic fertilizers are most widely shared reasons among farmers leading to their rejection of organic fertilizers. Farmers reject organic fertilizers because they do not understand clearly about the organic fertilizer. Lack of the farmers' knowledge about organic fertilizer made them uneager to use it.

Early decision. In the initial decision phase, someone select the activities that lead to the choice of using or not using the innovation. This decision includes further considerations whether they will try the innovation or not, if the innovation can be tried. Usually people do not accept an innovation without trying it first as a base to see possible usability of the innovation for them. The farmers' decision to use the organic fertilizer is about 71 percent. This 
indicates that farmers have already begun to receive and try the organic farming. Farmers who do not use organic fertilizers have some reasons such as fear of bearing a risk, complex fertilizers process and processing of the land cultivation that uses more manpower.

Table 2. Process of Farmers' Decision toward the Organic Rice

\begin{tabular}{ccc} 
Farming & & \\
\hline Process of Decision & $\begin{array}{c}\text { Total number } \\
\text { (person) }\end{array}$ & $\%$ \\
\hline Persuasion : & 74 & 74 \\
$-\quad$ Acceptable to use & 26 & 26 \\
$-\quad$ Unacceptable to use & & \\
First Decision : & 71 & 71 \\
- Use & 29 & 29 \\
- Not use & & \\
Confirmation : & 68 & 68 \\
- $\quad$ Seeking for information & 32 & 32 \\
- Not seeking for & & \\
$\quad$ information & & 15 \\
Last Decision : & 15 & 65 \\
- Organic & 65 & 20 \\
\hline$\quad$ Mix & 20 & \\
\hline
\end{tabular}

Confirmation. Confirmation comes after the decision is made to accept or reject an innovation over a long period. At this stage, a person tries to find information to strengthen the decision they have made, but they can change their decision if they receive conflicting messages. The awareness of seeking deeper information about organic fertilizers by farmers can be bigger. The farmers began to find other information related to the organic fertilizer both from the Institution or farmers group. There were only few farmers who did not want to find the information because the farmers were busy with farming and they did not want to know more. A huge interest in information seeking will ease them in understanding about organic fertilizer. Farmers tried to coordinate more with farmer groups and the institution concerning on organic fertilizer. However, farmers who are busy with their farming will not have the time to find out information about organic fertilizer.

\section{The Decision of Organic Rice Farming}

The organic fertilizers especially the manure fertilizers which are environmentally friendly have long been known and even be used by our ancestors. Therefore, the decision of the use of non organic fertilizer is bigger than those who do not use them. 20 percent of the entire farmers do not want to use organic fertilizer, because the land that they manage is not their own land, making them feel useless in using organic fertilizers. Moreover, there had been an assumption that after stopping the use of organic fertilizer they could not reap the result. Thus, most of them opted to mix between organic and inorganic fertilizers.

There are many farmers who are still reluctant to entirely use the organic fertilizers. 15 percent of farmers had already decided to use the pure organic fertilizers. Most of the farmers conducted the rice farming with a mixture of organic and inorganic fertilizers. This was conducted to anticipate the risk of failure or lower production if farming was directly using organic fertilizer. Based on the results of the analysis, it is revealed that the farmers' decision on organic rice farming was included in the category of good with an average score of 1.85 .

Table 3. Last Decision of Farmer toward the Organic Rice Frming

\begin{tabular}{llcc}
\hline Last Decision: & $\begin{array}{c}\text { Total number } \\
\text { (person) }\end{array}$ & $\%$ \\
\hline- & Organic & 15 & 15 \\
- & Mix & 65 & 65 \\
- & Non organic & 20 & 20 \\
\hline
\end{tabular}

\section{B. Risks of Organic Rice Farming}

1. Cost of Farming

The analysis of farming is conducted to find out the agricultural resource allocations made by farmers to earn the income from the results of farming. Every resource allocated in farming which includes the expenditure is called costs of farming. Various types of expenses in the rice farming such as the cost of depreciation of tools, labor costs, the cost of the means of agricultural production and other expenses in the form of taxes, irrigation, celebration, bawon and profit sharing. Tool of rice farming production includes seeds, fertilizers and pesticides.

The biggest tool depreciation cost is on the mixed farming because in this type of farming, the farmers still rely on pesticides requiring the sprayer tool for spraying. It also can be seen from the cost of pesticides that relatively higher than the other cost. The cost of human labor in the mixed system farming is also higher than others because this farming has two treatments which are organic and conventional have different handling require a lot of manpower as well. The cost of the organic and non-organic fertilizer that was expensed on the rice farming with the mixed system is relatively higher than the others. Fear of harvest failure caused farmers to spend the higher costs. The use of inorganic fertilizers is still conducted by a few organic rice farmers which the nature to loosen up the soil in the form of TSP. In the conventional rice farming, the use of fertilizer was dominated by inorganic fertilizers, whereas the organic fertilizer was the manure fertilizers from their own livestock.

Generally, the highest amount of farming costs is on mixed system farming because the expense for labor and the means of production are higher. The cost of organic rice farming is relatively higher than the cost of conventional rice farming because the organic rice farming requires more human labor. The labor is especially required for the fertilizer processing, fertilization and maintenance. 
Table 4. The Cost of Rice Farming in Planting Season 2017/2018

\begin{tabular}{lccc}
\hline \multicolumn{1}{c}{ Kinds of expense } & $\begin{array}{c}\text { Organic } \\
(\mathbf{R p})\end{array}$ & \multicolumn{1}{c}{$\begin{array}{c}\text { Mix } \\
(\mathbf{R p})\end{array}$} & $\begin{array}{c}\text { Conventional } \\
(\mathbf{R p})\end{array}$ \\
\hline Depreciation of tools & 5.570 & 57.540 & 29.601 \\
& & & \\
Labor : & & & \\
$\quad$ - Human & 616.673 & 617.206 & 92.000 \\
$\quad$ - Machine & 210.000 & 211.706 & 220.100 \\
$\begin{array}{l}\text { Means Of } \\
\text { Production : }\end{array}$ & & & \\
- Seed & 89.682 & 93.482 & 94.113 \\
- Organic & 203.163 & 218.616 & 95.963 \\
$\quad$ fertilizer & 22.218 & 141.614 & 172.421 \\
- Inorganic & & & \\
$\quad$ fertilizer & 13.097 & 30.929 & 13.500 \\
- Pesticides & 237.750 & 269.468 & 112.976 \\
Other cost & 1.398 .152 & 1.640 .559 & 830.672 \\
\hline Total & & & \\
\hline
\end{tabular}

\section{The Income of Farming}

The farming income is the subtraction between revenue and cost farming. Acceptance of farming depends on the rice production and the price of production which occurs at the time of sale. Beside the season, the price also depends on the variety and quality of rice that was produced. On the rice of local varieties usually the price is higher than the price of rice of varieties IR.

Table 5. The Income of Rice Farming in Planting Season

\begin{tabular}{lcrrr}
\multicolumn{1}{c}{ Items } & Unit & \multicolumn{1}{c}{ Organic } & \multicolumn{1}{c}{ Mix } & Conventional \\
\hline Production & $\mathrm{Kg}$ & 750 & 890 & 729 \\
Price & $\mathrm{Rp} / \mathrm{kg}$ & 4.750 & 4.600 & 4.300 \\
Acceptance & $\mathrm{Rp}$ & 3.562 .500 & 4.094 .000 & 3.134 .700 \\
$\begin{array}{l}\text { Cost } \\
\text { Income }\end{array}$ & $\mathrm{Rp}$ & 1.398 .152 & 1.640 .559 & 830.672 \\
$\begin{array}{l}\text { Per ha }(\mathrm{UT}=1650 \\
\left.\mathrm{m}^{2}\right)\end{array}$ & 2.164 .348 & 2.453 .441 & 2.304 .028 \\
\hline
\end{tabular}

The highest rice production is on the mixed systems of farming because the treatment and use of the means of production are relatively higher. The production of organic rice farming is relatively higher than the production of conventional rice. It was indicated that the fertility rates of land on the organic rice farming has experienced an improvement. In addition, to maintain and increase the production of rice, most farmers conducted the cultivation technical with TAJARWA (Tanam Jajar Legawa) system. Based on table 5, it is prominent that the highest income is on the mixed rice farming. It is according to the field condition that the farmer preferred mixed farming.

\section{The Risks of Rice Farming}

A risk is an uncertain condition and it occurs because of the threats that are accompanied by susceptibility to the circumstances. All activities conducted will raise a risk as well as the rice farming activities. The higher of the revenue obtained will make the higher risks borne by farmers as well as the cost of farming in which the higher fees charged to farmers, also the higher risk that would be faced by the farmer. The degree of the risk that would be faced by farmers can be seen from the variation coefficient of the farming, either the cost or revenue. The bigger variation coefficients of farming influenced the bigger the risk that would be faced by farmers.

Table 6. The Variation Coefficient of the Income of Rice

\begin{tabular}{lcccc}
\multicolumn{5}{c}{ Farming in Planting Season 2017/2018 } \\
\hline \multicolumn{1}{c}{ Items } & Unit & Organic & Mix & Inorganic \\
\hline $\begin{array}{l}\text { Average of } \\
\text { income }\end{array}$ & Rp & 2.164 .348 & 2.453 .441 & 2.304 .028 \\
$\begin{array}{l}\text { Standart } \\
\text { devition }\end{array}$ & & 2.005 .950 & 3.356 .566 & 2.880 .578 \\
$\begin{array}{l}\text { Variation } \\
\text { Coefficient }\end{array}$ & & 0,9268 & 1,3681 & 1,2502 \\
\hline
\end{tabular}

Based on the table 6 , it is obvious that the coefficient variation of the highest earnings risks is encountered in mixed farming system because the average cost of that farming is the highest with more diverse income variation. Organic rice farming has the lowest risk because of the earned income is relatively more equal than any other farming.

\section{CONCLUSION AND SUGGESTION}

A. Conclusion

1. The rice farmers' decision in the Kebonagung village of Imogiri district and Wijirejo village of Pandak district Bantul regency for implementing the organic rice farming is classified as good.

2. The organic rice farming has the lower risk than the conventional and mixed system.

\section{B. Suggestion}

The development of organic agriculture requires more farmers' intensive experience through mentoring activities in a group so that the decision process stages such as persuasion, early decision and the confirmation will be more powerful leading to the stronger final decision for organic rice farming.

Appropriate technology that can be applied is LEISA (Low External Input for Sus-tainable Agriculture) which is considered more realistic than the organic farming, because in addition to using natural and biological inputs it allows to use the input artificial chemicals, such as fertilizers and pesticides in limited quantities as long as the product are safe and healthy. Reduction of chemical inputs is conducted gradually so that the production of rice could be maintained. The technique of rice cultivation that is capable to increase the production is the technique of "Tajarwa" (Tanam Jajar Legawa).

\section{REFERENCES}

[1] B. Xie, W. Xiaorong, D. Zhuhong and Y. Yaping,. "Critical impact assessment of organic agriculture", J. Agr. En. Eth. vol. 16 pp. 297311,2003

[2] M. Canavari, G. M. Gazzani, R. Spadoni dan D. Regazzi, "Food safety and organic fruit demand in Italy: a survey", Brit. Fo. J. vol. 104 (3-5) pp. 220-232, 2002

[3] R. Connor and L. Douglas, "Consumer attitudes to organic foods" Nut. Fo. Sci., vol. 31 (4/5) pp. 254-258, 2002. 
[4] Sugiyono, Metode Penelitian Kuantitatif dan R \& D. Penerbit Alfabeta, Bandung, 2014

[5] W. Galo, Metode Penelitian. Pt Gramedia Widia Sarana Indonesia. Jakarta, 2002.

[6] Nasution, "Metode Research", Bumi Aksara, Jakarta, 2002

[7] M. Nazir, Metode Penelitian. Ghalia Indonesia, Jakarta, 1999 